\title{
Ethical approaches to teaching Aboriginal culture and literature in Spain
}

\section{Susan Ballyn}

The teaching of any subject, regardless of discipline, at whatever level of education, involves a teacher taking an ethical stance both towards the subject matter and the students. There has to be a commitment by the teacher to an application of what he or she believes to be the best, most honest, ethical approach in the classroom and to enable open constructive discussions among students. Furthermore, the ethics to which a teacher subscribes should, I believe, always be at the forefront of any teaching and clearly visible to the students. There is often discussion regarding the fact that at tertiary level there is room for little else other than cramming knowledge and preparing the individual to enter the labour market, to find their 'niche' as some call it. This is not so. And if it is so, then the educational system has lost its way and purpose. These are the crucial years when a young person will make many decisions which will have a lasting effect on both themselves and often their families. These are the years of putting to use the art of reasoning, of philosophic debate, of questioning the already learnt and opening horizons to new areas of thought and study. In short, of consolidating and grounding the individual, thus enabling him or her to take a responsible active role in society.

Although one tries to have an ethical base when teaching, my present concern with both did not actually crystallise until I began to teach Aboriginal culture and literature especially biography.

I was born and educated in England within a cultural background in which the British Empire and its history held the central role in what we learnt. Many of my generation will well remember the world map, which took prominent place in any classroom, with a proliferation of 'British' pink on it. Thus I was conditioned to conceptualise the world and its relationship to me in a very traditional British way. However, in my late teens I reversed the usual process of 'school to university' by going to live in Spain and have remained there ever since. I qualified as a secondary school teacher of English as a foreign language and worked in the private sector for several years before finally graduating in English at Barcelona University. It was here that the rest of my academic life was focused under the tutelage of my PhD supervisor, Doireann MacDermott, who had started 'Commonwealth Studies' at Barcelona in the 1960s. I became absorbed in studying Australian culture and literature, finally moving into the 
area of Postcolonial Studies, as it had then become, as a lecturer in the late 1980s. As Aboriginal culture formed part of three of the courses, I found myself questioning how I could actually teach this to Spanish students when I was neither Australian nor Aboriginal but British. It seemed to me that I was threefold removed from the subject I was going to teach. Did I in fact have an authoritative position from which I could actually approach the subject? It became quite clear to me then, that I had to work out some viable ethical approach which would allow me to open up Aboriginal culture and literature to students without academically re-colonising and perpetuating what I saw as the continued colonial situation in Australia with regard to its Indigenous people.

But what of my audience? Today the English Department has a fully developed postcolonial stream on its syllabus. To obtain a BA in English a student must undertake a four year undergraduate course. For first and second year students, 'An introduction to the Anglophone postcolonial world' is an obligatory course with modules on Africa, Australia, Canada, the Caribbean, India and New Zealand. The course is taught by various lecturers who cover the geographical areas of their expertise plus visiting lecturers. The set texts used in the course are looked at not so much from a theoretical literary point of view but rather as witnesses to and in depth studies of the social history and cultures of the nations concerned. For third and fourth year students each of these regions becomes a separate in depth optional subject, in the case of Australia titled 'The global village: the Pacific in film and literature'. The course takes Australia as its core and then moves out to compare and contrast with other Pacific nations, particularly New Zealand. At Postgraduate level we have a visiting Australian lecturer incorporated into our Masters course each year and there is also an online virtual Masters, independently run by the university, called 'The Asia Pacific region' in which Aboriginal Australia is part of a compulsory module in 'An introduction to the Pacific'. Of all the courses mentioned this is the only one taught in either Spanish or Catalan. The English Department teaches exclusively in English.

The bulk of the students come from Catalonia, an autonomous region with its own rich cultural heritage and language, and from the rest of Spain, often as part of the Seneca internal mobility programme. Other students are drawn from all parts of Europe under the European Erasmus Exchange scheme, from exchange programmes with North and South American universities and also from two Australian universities, La Trobe University and Southern Cross University. To date, Barcelona University has the largest number of Erasmus students in Spain. Increasingly and interestingly, we are now getting a small core of migrant students moving into tertiary education. Thus there is frequently a rich cultural diversity in the classes which often facilitates a range of cultural debates. 
So what ethics can be applied in dealing with Aboriginal culture and texts in such a class? Students can be surprisingly Eurocentric in their outlook, frequently reading autobiographies as windows on a world which they look at and judge from a Euro-western-theoretical perspective, displaying a disturbing tendency to remain within the comfort zone of the European. This euro-centrism needs to be constantly challenged by questioning their innate assumptions regarding their own identity together with the place and role of Europe in the world. When talking about Dreaming, for example, students will, albeit unwittingly, use terms such as 'myth' or 'legend', taking for granted that western terminology can easily connote and equate to Aboriginal belief systems. A whole debate must ensue from this in which views and opinions must be discussed and challenged, preferably by the students themselves, in order to right this skewed look at indigenous belief systems across the world. An ideological and responsible repositioning has to take place if we are to understand Aboriginal culture to any degree.

Spain is in essence an ideal place to work. Very little historic revision of Spanish colonialism has actually taken place in Spanish schools. Therefore the classroom can become a dynamic space of colonial and postcolonial repositioning in terms of the students' own national history. Working within an already culturally and linguistic plural environment such as Catalonia, can often serve as the trampoline for debate on the relationship between Catalonia and Spain, spreading out to take on reconsiderations of the colonisation of South America and the important parallels that can be drawn between the two systems of colonial invasion and consequent physical and cultural genocide. A discussion of the invasion of Australia and its consequences together with the increasingly retrograde policies of Prime Minister John Howard in Aboriginal affairs can lead to an invigorating insight into where we are today when we look at the situation in Chiapas, or the dispossession caused by intense logging and burning in the Amazon. It is this wealth of cross cultural possibilities that makes the Spanish classroom an ideal place for debate, for mapping out the need for social awareness, tolerance and an attempt at understanding where we have and are going wrong and what we can do about it. A student in Barcelona need only look at the rapidly changing demographic composition of their own society to realise that being at a tertiary institution has to involve more than sitting in an ivory tower and debating within the walls of academia. My objective is to get them to become outwardly thinking individuals able and willing to take on a responsible role as world citizens.

Each year I sit with the new texts and films we are going to watch and begin an ongoing monologue about how I am going to deal with this material. Each year old and new problems pop up. I am coming at Aboriginal culture right from the outside, three times removed and only able to make short yearly visits to the country. While I can read unlimited sources at home there is, I believe, no 
substitute for being on the land, for developing a bond with it in my own peculiar way and, most importantly, for those long personal conversations of learning with others. Certainly a valuable amount can be done through constant email contact but it is in no way a substitute for being in the country, meeting people, and having doors, previously unknown to one, opened. However, 'teaching from the outside' does enable me to help the students not to fall into some of the pitfalls I myself may have encountered along my way.

Student reactions to the Aboriginal texts and films used in class surface very rapidly. They tend to home in on the Aboriginal work, especially autobiographies, because it is all new and, in their words, 'exciting' to them. This can be and often has been problematical, leading students to want to do all their term work on Aboriginal film and writing. While this is no bad thing, it can lead to an exoticisation of the Aboriginal, a 'recolonising' from a European reading/seeing perspective and on rare occasions to a deeply worrying paternalistic attitude. All of these tendencies have to be contained and redirected. A statement made by a student recently when reading a non-Aboriginal author that ' $[\mathrm{t}]$ he book was not Australian literature because it was not authored by an Aboriginal and did not contain Aboriginal characters' is just the sort of remark which will lead to the debate as to how we should approach the texts and films, as to whether we as Europeans are in a position to categorise the material we are studying and finally to question the notion of the constant drive to categorise everything as we do in Europe.

I approach the Aboriginal texts/films within the European history of invasion, dispossession, genocide and on-going trauma. The students have access to a huge amount of electronic information in the form of articles, press links, reviews, journals and I impress upon them that any engagement with the work we are doing must move through a social-historical approach to a well documented analysis of current government intervention. As far as I am concerned any theoretical approach must wait.

Our first task, once the socio-historical background has been dealt with, is to attempt to come to the work with a clean slate. We need to listen if we are to understand, we need to realise that enabling ourselves to leap the cultural abyss that lies between us and Aboriginal culture, indeed that of any indigenous group around the world, has to be based on listening, absorbing, taking the texts away with us and thinking profoundly about what they are saying about themselves and us as outsiders. We must tread carefully across the bridge of cultural difference to establish a degree of intercultural understanding.

Respect, diffidence and, perhaps paradoxically, unencumbered positive engagement have become keywords in my approach. If we have listened to and understood as much as we can, then a responsible position of knowing can be reached. My own awareness of what I term 'responsible knowing' first surfaced 
on hearing Lauretta Ncobo speak to a crowded auditorium at Barcelona University many years ago. At the end of her talk there was a stunned silence. Eventually a student asked her what it was that she would wish us to take away from her talk. The reply was quick: 'You can never say you did not know!' Positive engagement with a culture signifies becoming proactive regarding that culture and the misconceptions that are so often bandied about, but always with an awareness that we can neither speak for the indigenous community concerned nor adopt a 'know it all' approach. We do not know it all, especially as outsiders, but what we do know and understand is what we can bring to bear on those who, for whatever reason, do not know. Television audiences in Spain are often offered documentaries about Aboriginal painting, dancing, traditional ways of life, but little or nothing comes across about contemporary art, urban environments, land rights or the political climate Aboriginal people are currently enduring. That is the arena where I would hope that students would indeed become proactive with what knowledge they have, not just with regard to Aboriginal culture, but across the board where injustice and lack of solidarity raises its head.

It may appear to the reader that what I am doing is throwing literary theory, social theory, all theory out of the window and merely indulging in a close reading of film and autobiographical and other texts. This is not actually the case, I believe that first we have to materialise, physicalise the text to later be able to approach in various theoretical ways. The theoretical approaches may be applied in term projects, in the electronic debating forum, in small group seminar work. I ask time and again: how can we use theory to come at a culture about which, initially, we know little or nothing? It seems to me that in coming to Aboriginal work from the very outside the text must be privileged over theory. 